\title{
O ALCANCE DOS DIREITOS SUCESSÓRIOS DO(A) COMPANHEIRO(A) COM O JULGAMENTO PELO STF DO RECURSO EXTRAORDINÁRIO $n^{\circ}$ 878.694/MG

\author{
THE REACH OF THE PARTER'S SUCESSION \\ RIGHTS WITH STF'S JUGDMENT OF THE
} EXTRAORDINARY RECOURSE nº 878.694/MG
}

\author{
GILLIAN SANTANA DE CARVALHO MENDES ${ }^{1}$ \\ ARMANDINO PINTO DE MOURA ${ }^{2}$
}

\section{RESUMO}

O presente artigo teve como objetivo analisar a situação atual do(a) companheiro(a) no direito sucessório, no Código Civil de 2002, em decorrência do julgamento do Recurso Extraordinário n 878.694/MG, em que o Supremo Tribunal Federal(STF) reconheceu e declarou a inconstitucionalidade do art. 1.790, do mencionado normativo. O STF equiparou a união estável ao casamento, para fins sucessórios, e determinou a aplicação, a ambos os casos, do regime estabelecido no artigo 1.829 do Código Civil de 2002. 0 procedimento metodológico consistiu numa pesquisa descritiva, apresentando a situação atual dos companheiros no direito sucessório brasileiro e qualitativa, analisando o entendimento do julgamento do Recurso Extraordinário 878.694/MG pelo STF. Concluiu-se que o STF deixou várias omissões em sua decisão, como não ter declarado a inclusão do companheiro ou companheira no rol de herdeiros necessários, previsto no art. 1.845 do CC/2002, bem como dizer se o convivente terá direito real de habitação, conforme regra do art. 1.831 do mesmo normativo. O STF também se omitiu quanto ao alcance da segurança jurídica de sua decisão, posto que, ao determinar que o entendimento do decisum fosse aplicado apenas aos inventários abertos e não findos, acabou por afrontar os artigos 1.784 e 1.787 do CC/2002.

PALAVRAS-CHAVE: Supremo Tribunal Federal. União Estável. Sucessão do (a) Companheiro(a).

1 Doutora em Direito e Políticas Públicas pelo Centro Universitário UNICEUB, Mestre em Direito Constitucional pela Universidade Federal do Ceará. Professora da Universidade Estadual do Piauí e do Centro Universitário UNINOVAFAPI, nos cursos de Direito da graduação e pós-graduação. ORCID: https://orcid.org/0000-0002-7149-1367. E-mail: gillian.santana@hotmail. com.

2 Especialização em Segurança Pública e Inteligência Policial/UESPI, Advogado. Pós-graduando em Direito Civil e Processo Civil. Graduação em Licenciatura Plena em Ciências-Matemática/UFPI, Direito/UFPI, Ex-Delegado de Polícia Civil/PI. ORCID: https://orcid.org/0000-0003-4835-5954.E-mail: apmdpc@gmail.com. 


\section{ABSTRACT}

The purpose of this article was to analyze the current situation of the partner in succession in the Civil Code of 2002, as a result of the judgment of Extraordinary Appeal No. 878.694 / MG, in which the Supreme Court (STF) recognized and declared the unconstitutionality of art. 1,790, of the mentioned normative. The Supreme Court equated the stable union with the marriage, for succession purposes, and determined the application, in both cases, of the regime established in article 1.829 of the Civil Code of 2002. The methodological procedure consisted of a descriptive research, presenting the current situation of the partners in Brazilian and qualitative inheritance law, analyzing the understanding of the judgment of Extraordinary Appeal 878,694 / MG by the STF. It was concluded that the STF left several omissions in its decision, such as not having declared the inclusion of a partner in the list of necessary heirs, provided for in art. 1,845 of CC / 2002, as well as saying whether the cohabiting person will have real right to housing rights, according to the rule of art. 1,831 of the same regulation. The STF also failed to take into account the scope of the legal certainty of its decision, since in determining that the understanding of the decision should be applied only to open and unfinished inventories, it ended up facing Articles 1,784 and 1,787 of CC / 2002.

KEY WORDS: Supremo Tribunal Federal. Stable Union. Succession of the Partner.

\section{INTRODUÇÃO}

A união estável é uma relação de fato entre um homem e uma mulher, de forma prolongada, sem ser formalizada, como é o casamento, mas com o objetivo de constituição de família. Esse regime de união estável é plenamente praticado na sociedade brasileira e amparado no seu sistema jurídico. Nesse sentido, a Constituição Federal de 1988, em seu artigo $226, \S^{\circ}$, reconheceu a união estável como entidade familiar e garantiu a facilitação de sua conversão em casamento, dando os primeiros passos para a equiparação dos direitos dos companheiros aos dos cônjuges, tanto no direito de família quanto nos direitos sucessórios.

Posteriormente a promulgação da Carta Magna, como complementação e aplicação do dispositivo supracitado, foram editadas as Leis 8.971/1994 e 9.278/1996, concedendo direitos aos companheiros, principalmente no que se refere à sucessão.

Com a vigência do Código Civil de 2002, houve no seu artigo 1.723 o reconhecimento da união estável como entidade familiar, configurando-se a referida união com a publicidade, continuidade, durabilidade e vontade de constituição de família, consolidando-se o desejo constitucional. No entanto, igualmente não ocorreu quando o direito sucessório tratou sobre a sucessão dos companheiros, que foi regulado no artigo 1.790, fazendo clara distinção em relação ao direito sucessório dos cônjuges, este regulado em seu artigo 1.829 e outros dispositivos, gerando muitos questionamentos no âmbito doutrinário e jurisprudencial.

Por meio do Recurso Extraordinário n 878.694/MG, julgado pelo Supremo Tribunal Federal (STF) em maio de 2017 e com Acórdão publicado em fevereiro de 2018, com efeito de repercussão geral, foi reconhecida e declarada a inconstitucionalidade do artigo 1.790 do Código Civil e a distinção que fez quanto ao regimes sucessórios entre cônjuges e companheiros, devendo ser aplicado, em ambos os casos, o regime estabelecido no artigo 1.829 do referido códex. 
Apesar do reconhecimento da equiparação do regime sucessório entre cônjuges e companheiros, tem-se como hipótese que o Supremo Tribunal não enfrentou, no decisum, a questão em sua plenitude, omitindo-se em relação a diversos dispositivos que permeiam esse regime jurídico. Nesse sentido, analisar-se-ão questões que não ficaram claras ou omissas quanto a equiparação, como: encontrarem-se ou não os companheiros no rol de herdeiros necessários, como previsto no art. 1.845 do CC/2002 em relação aos cônjuges, e se incidem sobre eles as regras previstas nos artigos 1.789 e 1.846 a 1.849, que tratam da proteção da parte legítima, o que gera para o convivente restrições na doação e no testamento.

Analisar-se-á, também, qual foi o alcance dado pelo STF em relação aos companheiros sobre o direito real de habitação assegurado aos cônjuges no art.1.831 do CC/2002, bem como a aplicação, pela Suprema Corte, da sua decisão, aos inventários judiciais e extrajudiciais abertos e ainda não findos.

Com a finalidade de analisar o alcance da decisão do STF no julgamento do Recurso Extraordinário n 878.694/MG, acerca da sucessão dos companheiros, o presente artigo foi dividido em três tópicos, sendo que inicialmente será apresentado um panorama sobre a situação atual do(a) companheiro(a) no direito sucessório conforme o Código Civil, abordando também o conceito e requisitos da união estável. O segundo tópico trará uma abordagem sobre o RE 878.694/MG, em que o STF reconheceu e declarou a inconstitucionalidade do artigo 1.790 do CC/2002 e equiparou os regimes sucessórios entre cônjuges e companheiros. 0 terceiro e último exporá os direitos sucessórios do(a) companheiro(a) no julgamento do Recurso Extraordinário n 878.694/MG, abordando o alcance da Suprema Corte sobre herdeiro necessário, direito real de habitação e aplicação da decisão aos inventários judiciais e extrajudiciais abertos e ainda não findos.

Assim, este estudo tem a finalidade de demonstrar a nova regra de sucessão para os que convivem em união estável, após o reconhecimento da inconstitucionalidade do artigo 1.790 pelo STF, destacando, de forma específica, o alcance da decisão junto ao Supremo Tribunal Federal, referente a diversos outros dispositivos do Código Civil que conformam esse regime jurídico.

\section{SITUAÇÃO ATUAL DO(A) COMPANHEIRO(A) NO DIREITO SUCESSÓRIO NO CÓDIGO CIVIL}

No Brasil, por longo período histórico, a união prolongada entre o homem e a mulher, sem as formalização do casamento, morando ou não sob o mesmo teto, foi considerada como concubinato (PENA JÚNIOR, 2017). O concubinato consiste na relação entre homem e mulher, dentre os quais um ou outro não é livre para casar, de forma que o concubinato não é reconhecido pela legislação. Diferentemente, na união estável os partícipes são livres para constituírem casamento.

$\mathrm{Na}$ união estável, a relação entre o homem e a mulher é prolongada, continua e duradoura, tendo como objetivo, o de constituir laços familiares, podendo ser convertida em casamento. No concubinato, a relação entre o homem e a mulher, embora não eventual, não 
tem o objetivo de constituir família e, como foi exposto, pelo menos um dos conviventes encontra-se legalmente impedido de casar.

Com a promulgação da Constituição Federal de 1988 e o reconhecimento da união estável como entidade familiar, foi significativo o avanço e proteção jurídica desta situação de fato no Direito de Família. Nesse sentido, afirmam Farias e Rosenvald (2015, p. 446),

A partir do $\S^{\circ}$ do art. 226 da Carta Cidadã de 1988 é possível visualizar a união estável, também chamada de companheirismo, como uma situação de falto existente entre duas pessoas, de sexos diferentes e desimpedidas para casar, que vivem juntas, como se casadas fossem (convivência more uxório), caracterizando uma entidade familiar.

Farias e Rosenvald (2015) ainda acrescentam que a união estável é, na verdade, um casamento de fato, decorrente das relações sociais e naturais de afeto, da vontade das partes envolvidas, que em razão da liberdade que experimentam, simplesmente não desejam se curvar às formalidades do casamento. Portanto, legítima a proteção concedida pela Carta Magna.

Posteriormente, em 29 de dezembro de 1994, foi editada a Lei 8.971, que regulou os direitos dos companheiros a alimentos e à sucessão. No que diz respeito aos direitos sucessórios, assegurou a(o) companheira(o) sobrevivente o usufruto de quarta parte dos bens, havendo filhos, ou de metade no caso de não haver filhos, mas sobrevivendo ascendentes e ainda o direito à totalidade da herança na falta de descendente e ascendente. Nas duas primeiras situações, o (a) companheiro (a) somente terá direito ao usufruto dos bens do de cujus até enquanto não constituir nova união.

Em 10 de maio de 1996, nova lei foi editada, a Lei 9.278/1996, que regulamentou o art. 226, §3 ${ }^{\circ}$ da Constituição Federal (BRASIL, 1988), reconhecendo a união estável entre o homem e a mulher como entidade familiar, assegurando aos companheiros o direito de herdar e o direito real de habitação, dentre outros.

As Leis 8.971/1994 e 9.278/1996 foram tacitamente revogadas, em razão de as matérias nelas tratadas terem sido incluídas no Código Civil de 2002, que incorporou nos artigos 1.723 a 1.727 os princípios básicos das referidas Leis (BRASIL, 2002). Nesse sentido, afirma Gonçalves (2012, p. 608),

Restaram revogadas as mencionadas Leis n. 8.971/94 e 9.278/96 em face da inclusão da matéria no âmbito do Código Civil de 2002, que fez significativa mudança, inserindo o título referente à união estável no Livro de Família e incorporando, em cinco artigos (1.723 a 1.727), os princípios básicos das aludidas leis, bem como introduzindo disposições esparsas em outros capítulos quanto a certos efeitos, como nos casos de obrigação alimentar (art. 1.694).

Ainda destaca Gonçalves (2012) que o Código Civil de 2002 tratou, nos dispositivos supra referidos, dos aspectos processuais e patrimoniais, ficando para o direito das sucessões o efeito patrimonial sucessório, conforme previsto no art. 1.790 do CC/2002 (BRASIL, 2002).

O Código Civil de 2002 fez menção expressa do direito real de habitação do cônjuge, omitindo-se em relação a(o) companheira (o), o que embora sem previsão no referido codex, ainda se proclama a subsistência do artigo $7^{\circ}$, parágrafo único, da Lei 9.278/1996, que asse- 
gurava aos companheiros sobreviventes o direito real de habitação relativamente ao imóvel destinado à residência da família.

A doutrina diverge quanto a aplicabilidade do artigo supracitado, Pereira (2016) afirma que houve revogação tácita de tudo que não foi incorporado pelo Código Civil, Gonçalves (2012) argumenta não ter havido revogação expressa da citada lei quanto ao direito real de habitação do(a) companheiro(a), bem como não haver incompatibilidade do benefício nela previsto com qualquer dispositivo do Código Civil (BRASIL, 2002). Ainda se invoca, por meio de interpretação analógica, que o direito real de habitação assegurado ao cônjuge no art. 1.831, do Código Civil de 2002, deve ser estendido aos companheiros.

Mesmo na falta de previsão no Código, sustenta uma corrente doutrinária sido a subsistência do art. $7^{\circ}$, parágrafo único, da Lei 9.278/96, que defere ao companheiro sobrevivente o direito real de habitação relativamente ao imóvel destinado à residência da família. Argumenta-se, em defesa da companheira, não ter havido revogação expressa da referida lei, bem como inexistir incompatibilidade do benefício nela previsto com qualquer dispositivo do novo Código. Invoca-se, ainda, a extensão analógica do mesmo direito assegurado ao cônjuge sobrevivente no art. 1.831 do mesmo diploma.

Nessa linha, o Enunciado 117 do Conselho da Justiça Federal, aprovado na I Jornada de Direito Civil, realizada em Brasília em setembro de 2002: "O direito real de habitação deve ser estendido ao companheiro, seja por não ter sido revogada a previsão da Lei 9.278/96, seja em razão da interpretação analógica do art. 1.831, informado pelo art. 6² caput, da CF/88", (GONÇALVES, 2012, p.189-190)

Para o Supremo Tribunal Federal as Leis 8.971/94 e 9.278/96 tiveram seus dispositivos revogados, como se pode observar no trecho da Ementa do Acórdão do julgamento do RE 878.694-MG, de 10.05.2017, em que foi reconhecida a inconstitucionalidade do art. 1.790, do Código Civil de 2002

[...] Assim sendo, o art. 1.790 do Código Civil, ao revogar as Leis nº 8.971/94 e 9.278/96 e discriminar a companheira (ou companheiro), dando-Ihe direitos sucessórios bem inferiores aos conferidos à esposa (ou ao marido), entra em contraste com os princípios da igualdade, da dignidade humana, da proporcionalidade como vedação à proteção deficiente, e da vedação do retrocesso[...].

Assim, pode-se afirmar que parte da doutrina e o STF concordam a vigência do Código Civil de 2002 estabeleceu o direito sucessório do(a) companheiro(a), revogando tacitamente todas as disposições anteriores.

Foi no artigo 1.790 que o Código Civil (BRASIL, 2002) regulou o direito sucessório das pessoas que convivem entre si em união estável, consubstanciando, em linhas gerais, que o(a) companheiro(a) participa da sucessão somente quanto aos bens adquiridos onerosamente na vigência do casamento, de acordo com as seguintes disposições: a) se concorrer com filhos comuns, terá direito a uma quota equivalente ao que couber a estes; b) se concorrer apenas com descendentes do autor da herança terá direito à metade do que tocar a cada um deles; c) se concorrer com qualquer outro parente sucessível, o (a) companheiro(a) sobrevivente terá direito apenas a um terço da herança e d) somente quando não houver parentes sucessíveis é que terá direito à totalidade da herança. 
A sucessão do cônjuge não refere-se apenas a bens onerosos adquiridos na constância da convivência, e nem o cônjuge concorre com qualquer parente sucessível que não sejam descendentes ou ascendentes.

Os direitos sucessórios do(a) companheiro(a) em muito se distanciam da sucessão patrimonial do cônjuge, conforme pode ser observado no artigo 1.829 do Código Civil. Em breve análise dos dois dispositivos, os artigos 1.790 e 1.829 do CC/2002, vê-se claramente a diferença do regime de sucessão do cônjuge e da companheira ou companheiro, o que gerou muitos questionamentos a respeito da inconstitucionalidade do art. 1.790, do citado diploma, no âmbito do judiciário (BRASIL, 2002).

Coube ao Supremo Tribunal Federal, ao apreciar o Tema 809, relativo ao RE 878.694/ $M G$, reconhecer ser inconstitucional a distinção de regimes sucessórios entre cônjuges e companheiros prevista no art. 1.790 do CC/2002, determinando que seja aplicado, tanto nas hipóteses de casamento quanto de união estável, o regime do art. 1.829 do CC/2002, onde se inclui o cônjuge na ordem da vocação hereditária e nada se mencionava a respeito do(a) companheiro(a). Observe-se que o STF não revogou o artigo 1.790, pois somente ao Poder Legislativo é possível tal feito, (ANDRADE, 2018).

Com a referida decisão, atualmente também se aplica aos companheiros o mesmo regime sucessório previsto para os cônjuges disposto no artigo 1.829 do Código Civil de 2002.

Contudo, em sua decisão (RE 878.694/MG), o STF não esclareceu alguns questões emblemáticas: se o companheiro possui direito real de habitação, previsto no art. 1.831 do CC/2002 ao cônjuge; se deve ser incluído ou não no rol de herdeiros necessários do art. 1.845 do CC/2002, pois os herdeiros necessários, dentre eles os descendente, ascendentes e cônjuge, têm direito a não serem privados da parte legítima, ou seja, cinquenta por cento da herança.

Da mesma forma, a Suprema Corte, ao determinar que a decisão que estabeleceu a inconstitucionalidade do artigo 1.790 do CC/2020 fosse aplicada aos inventários judiciais e extrajudiciais já abertos e ainda não findos, nada explicou sobre a afronta desse entendimento ao disposto nos artigos 1.784 e 1.787 do CC/2002, que determinam que a sucessão e a legitimação para suceder são reguladas pela lei vigente na data da abertura daquela.

Assim, o STF se omitiu ao não esclarecer se são aplicadas, aos companheiros, as regras de diversos dispositivos do $\mathrm{CC} / 2002$ que estão em conformidade com o regime jurídico dos cônjuges. Há necessidade, portanto, de que a Corte apresente o alcance da tese do julgamento e quais as regras e dispositivos do regime sucessório do cônjuge que devem ser aplicados aos companheiros, bem como que esclareça qual a lei que deverá ser aplicada à sucessão dos companheiros. 


\section{A DECLARAÇÃO DE INCONSTITUCIONALIDADE DO ARTIGO 1.790 DO CC/2002 COM O JULGAMENTO DO RECURSO EXTRAORDINÁRIO No 878.694/MG PELO STF}

Em 10 de maio de 2017, o Supremo Tribunal Federal, concluiu o julgamento referente à inconstitucionalidade do artigo 1.790 do CC/2002, que tratava diferentemente do cônjuge o (a) companheiro(a) sobrevivente quanto aos direitos sucessórios. A decisão definitiva foi impulsionada pelo Recurso Extraordinário n 878.694/MG, que teve como Relator, o Ministro Luís Roberto Barroso.

O conflito que gerou o processo acima referido, deu-se por conta do conflito que passou a existir após a morte do autor da herança, entre os seus irmãos e a recorrente, com quem vivia em união estável. 0 de cujus não deixou testamento e passou a existir pretensão em relação ao seu patrimônio por ambas as partes: irmãos e companheira. O falecido possuía bens e não tinha descendentes, nem ascendentes, tendo como parentes mais próximos apenas três irmãos, os quais figuraram no polo passivo do recurso.

A decisão do juiz de primeiro grau reconheceu o direito da companheira sobrevivente à totalidade da herança deixada pelo companheiro falecido, excluindo da sucessão os irmãos do de cujus, ainda lhe concedendo o direito real de habitação. Portanto, o julgador de primeira instância aplicou ao caso o inciso III do artigo 1.829 do CC/2002, dando igual tratamento ao instituto da união estável em relação ao casamento.

No caso presente, em sendo aplicada a regra estabelecida no inciso III do artigo 1.790 do $\mathrm{CC} / 2002$, os irmãos vivos, que são colaterais de $2^{\circ} \mathrm{grau}$, concorreriam à herança com a companheira, cabendo a esta apenas um terço dos bens deixados pelo companheiro falecido.

Inconformados, os irmãos do falecido recorreram da decisão ao Tribunal de Justiça de Minas Gerais (TJ-MG) que, partindo da premissa da constitucionalidade do art. 1.790 do $\mathrm{CC} / 2002$, deu provimento à apelação, nos termos do inciso III do art. 1.790, limitando o direito da companheira a um terço dos bens adquiridos onerosamente durante a existência da união estável, excluindo-se os bens particulares do companheiro.

Descontente com a decisão do juízo de $2^{\circ} \mathrm{grau}$, a companheira do autor da herança interpôs Recurso Extraordinário junto ao Supremo Tribunal Federal, como última oportunidade de recurso, sustentando em suas razões que o regime sucessório estabelecido no artigo 1.790 do CC/2002 é incompatível com a Carta Magna, com o dever estatal garantido por ela relativo a proteção à família, de acordo com o previsto no art. 226 , $3^{\circ}$, da CF/88. Anunciando que o regime sucessório a ser aplicado ao seu caso deveria ser aquele idêntico à sucessão do cônjuge. A recorrente expôs como fundamento para tal pretensão o princípio da igualdade insculpido no art. $5^{\circ}$ da Carta da República e o reconhecimento da união estável promovido no artigo 226 acima indicado.

Em sede de contrarrazões ao Recurso Extraordinário, um dos recorridos defendeu a constitucionalidade do art. 1.790 do CC/2002, alegando que a CF/88 reconheceu a união estável como entidade familiar, porém não a equiparou ao instituto do casamento.

O Supremo Tribunal Federal finalizou o julgamento, decidindo, por maioria de votos, dar provimento ao Recurso Extraordinário n 878.694/MG, para reconhecer a inconstitucionali- 
dade do art. 1.790 do $\mathrm{CC} / 2002$, declarando o direito da recorrente em participar da totalidade da herança deixada por seu companheiro, equiparando o regime sucessório dos companheiros ao do cônjuge, na forma no art. 1.829 do CC/2002.

A ementa da decisão do Recurso Extraordinário 878.694/MG, publicada em fevereiro de 2018, foi apresentada nos termos a seguir:

DIREITO CONSTITUCIONAL E CIVIL. RECURSO EXTRAORDINÁRIO. REPERCUSSÃO GERAL. INCONSTITUCIONALIDADE DA DISTINÇÃO DE REGIME SUCESSÓRIO ENTRE CÔNJUGES E COMPANHEIROS.

1. A Constituição brasileira contempla diferentes formas de família legítima, além da que resulta do casamento. Nesse rol incluem-se as famílias formadas mediante união estável.

2. Não é legítimo desequiparar, para fins sucessórios, os cônjuges e os companheiros, isto é, a família formada pelo casamento e a formada por união estável. Tal hierarquização entre entidades familiares é incompatível com a Constituição de 1988.

3. Assim sendo, o art. 1790 do Código Civil, ao revogar as Leis $n^{\circ}$ s 8.971/94 e 9.278/96 e discriminar a companheira (ou o companheiro), dando-lhe direitos sucessórios bem inferiores aos conferidos à esposa (ou ao marido), entra em contraste com os princípios da igualdade, da dignidade humana, da proporcionalidade como vedação à proteção deficiente, e da vedação do retrocesso.

4. Com a finalidade de preservar a segurança jurídica, o entendimento ora firmado é aplicável apenas aos inventários judiciais em que não tenha havido trânsito em julgado da sentença de partilha, e às partilhas extrajudiciais em que ainda não haja escritura pública.

5. Provimento do recurso extraordinário. Afirmação, em repercussão geral, da seguinte tese: "No sistema constitucional vigente, é inconstitucional a distinção de regimes sucessórios entre cônjuges e companheiros, devendo ser aplicado, em ambos os casos, o regime estabelecido no art. 1.829 do CC/2002".

Assim, de acordo com a decisão do STF exposta, no entendimento da maioria dos ministros do STF, vencidos apenas os Ministros Dias Toffoli, Marco Aurélio e Ricardo Lewandowski, as regras da Constituição Federal contemplam diferentes formas de famílias, além da que resulta do casamento, e nesse rol se incluem as famílias formadas mediante união estável. Afirma a decisão não ser legítimo desequiparar, para fins sucessórios, a família formada pelo casamento e a formada pela união estável.

Portanto, com a decisão supracitada, o art. 1.790 do CC/2002 perdeu sua aplicabilidade prática e o companheiro ou companheira passa a figurar, ao lado do cônjuge, na ordem de sucessão legítima prevista no art. 1.829 do CC/2002 (BRASIL, 2002).

Contudo, há que se observar que o regime sucessório do cônjuge não se restringe ao dispositivo do artigo 1.829 do CC/2002, havendo diversos outros desse diploma que tratam sobre a sucessão do cônjuge, ficando em aberto para os companheiros, como já tratado, o direito real de habitação e configuração da condição de herdeiro necessário, como por exemplo.

Essa foi a linha de entendimento do Instituto Brasileiro de Direito da Família, ao embargar a decisão do STF no Recurso Extraordinário n 878.694/MG, argumentando, em resumo, 
que no regime sucessório do cônjuge, além das regras dispostas no art. 1.829 do CC/2002, há vários outros dispositivos do referido diploma que conformam esse regime jurídico, em particular o art. 1.845. Requereu o embargante que a Suprema Corte esclarecesse o alcance da tese de repercussão geral, no sentido de mencionar as regras e dispositivos legais do regime sucessório do cônjuge que devem se aplicar aos companheiros.

O Tribunal, porém, rejeitou os embargos, conforme ementa da decisão, que a seguir se destaca:

DIREITO CONSTITUCIONAL E CIVIL. EMBARGOS DE DECLARAÇÃO EM RECURSO EXTRAORDINÁRIO. REPERCUSSÃO GERAL. APLICABILIDADE DO ART. 1.845 E OUTROS DISPOSITIVOS DO CÓDIGO CIVIL ÀS UNIÕES ESTÁVEIS. AUSÊNCIA DE OMISSÃO OU CONTRADIÇÃO.

1. Embargos de declaração em que se questiona a aplicabilidade, às uniões estáveis, do art. 1.845 e de outros dispositivos do Código Civil que conformam o regime sucessório dos cônjuges.

2. A repercussão geral reconhecida diz respeito apenas à aplicabilidade do art. 1.829 do Código Civil às uniões estáveis. Não há omissão a respeito da aplicabilidade de outros dispositivos a tais casos.

3. Embargos de declaração rejeitados. (STF, Emb. Decl. no RE 878.694/MG, Rel. Min. Luis Roberto Barroso)

Apesar dos argumentos do STF na decisão que rejeitou os embargos, analisando a decisão relativa ao julgamento do Recurso Extraordinário n 878.694/MG, pode-se perceber que a Corte igualou o regime sucessório entre cônjuges e companheiros, impondo a aplicação das regras do art. 1.829 do CC/2002. Porém, é inegável que a Corte se omitiu quanto à aplicabilidade, às uniões estáveis, de diversos outros dispositivos do CC/2002 que conformam o regime sucessório do cônjuge, citando-se, a título de destaque, o art. 1.845, que trata do rol de herdeiros necessários.

\section{AS OMISSÓES NO JULGAMENTO DO RECURSO EXTRAORDINÁRIO No 878.694/MG, QUANTO AO DIREITO SUCESSÓRIO DO(A) COMPANHEIRO(A).}

Como já amplamente tratado, o Supremo Tribunal Federal concluiu o julgamento do Recurso Extraordinário n 878.694/MG, com repercussão geral, unificando sua decisão para outros casos semelhantes, tendo sido fixada a tese de que, de acordo com os princípios e garantias constitucionais vigentes, não comporta mais a distinção relativa aos direitos sucessórios entres cônjuge e companheiros, devendo ser aplicado, para ambos, as disposições constantes no artigo 1.829 do Código Civil de 2002.

Tendo, portanto, o Supremo Tribunal Federal equiparado, para fins sucessórios, os cônjuges e companheiros, isto é, a família formada pelo casamento e a formada por união estável, sob o fundamento de que assim resguardava e cumpria dos preceitos constitucionais vigentes, foi omisso quanto a outros direitos que, também, versam sobre sucessão do cônjuge, mas que não se encontravam descritos no art. 1.829 do CC/2002, como a inclu- 
são do(a) companheiro (a) no rol de herdeiros necessários, o direito real de habitação do(a) companheiro e, bem como sobre as regras sucessórias dispostas no Código Civil quanto ao momento da abertura da sucessão e a lei a regula.

\subsection{O(A) COMPANHEIRO(A) COMO HERDEIRO}

\section{NECESSÁRIO NO ART. 1.845}

Embora o Supremo Tribunal Federal, em sua decisão no julgamento do Recurso Extraordinário n 878.694/MG, tenha equiparado cônjuges e companheiros para fins sucessórios, aplicando-se, tanto para a união estável quanto para o casamento, as regras do art. 1.829 do CC/2002, não se pronunciou se também deverão ser aplicadas aos companheiros as regras do dispositivo do artigo 1.845, que estabelece o rol de herdeiros necessários: descendentes, ascendentes e cônjuge, sem fazer qualquer menção ao companheiro ou companheira.

Herdeiro necessário, também, denominado legitimatário ou reservatário, segundo Gonçalves (2012, p.205) " é o descendente (filho, neto, bisneto etc) ou ascendente ( pai, avô, bisavô etc), sucessíviel, ou seja, é todo parente em linha reta não excluído da sucessão por inidignidade ou deserdação, bem como o cônjuge ( CC, ART. 1845)", e quem consta neste referido rol possui proteção sucessória, limitando o autor da herança de dispor livremente de seu patrimônio, uma vez que os herdeiros necessários têm direito à metade dos bens da herança, constituindo-a legítima, conforme regra do art. 1.846 do CC/2002, somente podendo ser destituídos, em casos de indignidade e deserdação.

A omissão deixada pelo STF gera muitos questionamentos relativos ao Direito das Sucessões e muitas consequências, como dúvidas acerca da efetivação ou não deste direito. A esse respeito, TARTUCE (2019) destaca que a inclusão do companheiro no rol de herdeiros necessários teria três efeitos, a seguir descritos.

O primeiro efeito que se aponta, se considerado o companheiro como necessário, seria a proteção de sua legítima, gerando restrições na doação e no testamento, em razão da incidência das regras previstas nos arts. 1.789 (disponibilidade pelo testador de apenas metade da herança), 1.846 (constituição de legítima) e 1.849 do CC/2002 (possibilidade de ser herdeiro testamentário e legtítimo).

Como segundo efeito, advindo da inclusão dos companheiros no rol dos herdeiros necessários, seria a compreensão da ruptura do testamento na ignorância da existência de companheiro vivo, de acordo com a inteligência do art. 1.974 do Código Civil de 2002.

E como último efeito, o convivente, como herdeiro necessário, tem o dever de colacionar os bens recebidos em antecipação, como previsto nos arts. 2.002 a 2.012 do CC de 2002, sob pena de serem considerados sonegados, nos termos dos artigos 1.992 a 1.996, quando igualmente é reconhecido ao cônjuge.

Embora o Instituto Brasileiro de Direito de Família (IBDFAM) tenha ingressado com embargos, alegando que o acórdão do RE n 878.694/MG teria se omitido com relação a inclusão ou não do companheiro como herdeiro necessário, conforme regra do art. 1.845 do $\mathrm{CC} / 2002$, o Tribunal os rejeitou por unanimidade, pontuando o relator que não havia omissão a ser sanada: 
Não há que se falar em omissão do acórdão embargado por ausência de manifestação com relação ao art. 1.845 ou qualquer outro dispositivo do Código Civil, pois o objeto da repercussão geral reconhecida não os abrangeu. Não houve discussão a respeito da integração do companheiro ao rol de herdeiros necessários, de forma que inexiste omissão a ser sanada, (STF, Emb. Decl. no RE 878.694/MG, Rel. Min. Luis Roberto Barroso).

A rejeição dos embargos de declaração propostos pelo IBDFAN junto ao STF não resolveu o questionamento sobre a inclusão ou não do companheiro como herdeiro necessário. Nesse sentido, as palavras de TARTUCE (2019, p. 244):

A posição do presente autor é no sentido de que essa rejeição desses embargos, ocorrida em outubro de 2018, não resolveu o dilema, devendo a doutrina e a jurisprudência - notadamente do STJ - responder, em interpretação ao decisum anterior do STF, se o companheiro é ou não herdeiro necessário.

Permanece, assim, diante da omissão do STF, o justo questionamento sobre a necessidade de se esclarecer a respeito da inclusão ou não do(a) companheiro(a) como herdeiro necessário na disposição do art. 1.845/2002, vez que este artigo estabelece o rol de herdeiros necessários, incluindo o cônjuge, nada mencionando a respeito do companheiro ou companheira.

\subsection{O DIREITO REAL DE HABITAÇÃO DO(A) COMPANHEIRO(A)}

No mesmo julgamento do Recurso Extraordinário n 878.694/MG, ao equiparar o cônjuge e companheiro, para fins sucessórios, isto é, a família formada pelo casamento e a formada pela união estável, o STF também nada mencionou quanto ao direito real de habitação do companheiro.

É certo que a este respeito nada havia sido argumentado no julgamento original e que o direito real de habitação dos companheiros já vinha sendo debatido e reconhecido pela doutrina e jurisprudência. Porém, a mudança provocada pela decisão no direito sucessório em relação ao cônjuge e companheira ou companheiro, exigiu a manifestação da Corte sobre o direito real de habitação do(a) companheiro(a), principalmente no que diz respeito à extensão desse direito, entendimento ainda não pacificado.

Embora o STF tenha mencionado que a vigência do Código Civil de 2002 revogou tacitamente todas as leis infraconstitucionais anteriores que tratavam sobre o direito sucessório dos companheiros, a doutrina não é unânime a este respeito, e como o STF calou-se, há que se indagar se o direito real de habitação do(a) companheiro(a) lhe é assegurado em razão da subsistência do art. $7^{\circ}$, parágrafo único, da Lei 9.278/1996, ou lhe é reconhecido esse direito de forma equiparada ao cônjuge, na forma prescrita no art. 1.831 do CC/2002. Nesse particular, se ressalta que os dois dispositivos têm conteúdos distintos.

É de se entender que o direito real de habitação está amparado na regra disposta no art. 1.831 do CC/2002, embora seja mencionado apenas o nome do cônjuge, é de se interpretar que a fundamentação da decisão do STF sobre a inconstitucionalidade do art. 1.790 foi que os direitos sucessórios entre o cônjuge e companheiro(a) não poderiam ser divergentes, também não pode ser o direito real de habitação (BRASIL, 2002). Ademais, este foi o entendimento do Enunciado do Conselho de Justiça Federal, por conta da I Jornada de Direito Civil. 
O Enunciado n. ${ }^{\circ} 117$ do CJF/STJ estabeleceu dois critérios para que o direito real de habitação dos companheiros seja mantido: a) que não houve revogação expressa da Lei 9.278/1996 e b) que há um direito permanente e constitucional de moradia. E após, a decisão do Recurso Extraordinário do STF é possível que o referido Enunciado tivesse mais outro critério: o da igualdade entre os direitos sucessórios dos cônjuges e companheiros.

\subsection{A DECISÃO DO STF NO RE 878.694/MG AOS PROCESSOS PENDENTES.}

É inquestionável que a decisão tomada pelo STF no julgamento do RE 878.694/MG provocou mudanças significativas no direito sucessório ao equiparar, para esses fins, os cônjuges aos companheiros. $\mathrm{Na}$ oportunidade da decisão, muitos processos de inventários ainda se encontravam tramitando, referentes a herança de quem havia falecido antes da publicação do decisum.

Com o argumento de preservação da segurança jurídica, o STF determinou que a decisão deve ser aplicada apenas aos processos de inventários não findos, conforme trecho da ementa que se destaca a seguir:

[...] Com a finalidade de preservar a segurança jurídica, o entendimento ora firmado é aplicável apenas aos inventários judiciais em que não tenha havido trânsito em julgado da sentença de partilha, e às partilhas extrajudiciais em que ainda não haja escritura pública [...].

Com o entendimento firmado no julgamento, o STF pretendeu definir o alcance da decisão tomada, com o propósito de conceder segurança às relações jurídicas sucessórias envolvendo interesses de cônjuges e companheiros, imprimindo, inclusive, as normas estabelecidas no Código de Processe Civil que tratam sobre a lei processual no tempo, contemplando o sistema do isolamento dos atos processuais, no qual a lei nova é aplicada aos processos pendentes, (MEDINA, 2019).

É inegável que os efeitos da decisão do RE 878.694/MG atingiram outros dispositivos do Código Civil, além das regras do art. 1.829, que restaram em aberto, visto que o STF não enfrentou essa questão, conforme já se discorreu. Quanto à modulação dos efeitos do decisum, aqui pontuado, o Tribunal determinou sua aplicação aos inventários que não tivessem ainda sentença transitado em julgado e partilhas extrajudiciais que não possuíssem ainda escritura pública, por ocasião da publicação da decisão, ou seja, aos que se referem às sucessões abertas antes da publicação da decisão do STF, o que fere dispositivos do Código Civil quanto às regras de sucessão, especialmente, o seu o artigo 1.787, que dispõe sobre a lei que regula a sucessão, como a lei vigente ao tempo de sua abertura.

Nesse ponto, a decisão do STF, com a limitação imposta pelo Tribunal, não apreciando os seus efeitos nos demais dispositivos do Código Civil, acabou não trazendo a segurança jurídica pretendida, posto que a sucessão e a legitimação para suceder são reguladas pela lei vigente ao tempo da abertura daquela, conforme dispõe os artigo 1.787 do CC/2002, mais uma omissão, por não ter considerado o STF, a hipóteses de abertura da sucessão do(a) companheiro(a) antes da vigência do Código Civil de 2002, uma vez que seu artigo 1.790 foi considerado inconstitucional. 
Resta evidente que o Tribunal supramencionado, ao modular a aplicação de sua decisão, determinando a aplicação aos inventários judiciais e às partilhas extrajudiciais abertos e ainda não findos, afrontou não somente s normas dos artigo1.787, mas também, do 1.784, que dispõe que o momento da transmissão da herança é o momento da morte, ambos do Código Civil de 2002.

O STF, embora questionado sobre o alcance da decisão através dos embargos já citados, os rejeitou e não enfrentou a questão, deixando a dúvida em aberto e o questionamento sobre a real segurança jurídica do decisum.

O presente questionamento poderia ter sido, de pronto, eliminado, preservando a segurança jurídica das sucessões abertas e ainda não findas, se o referido Tribunal tivesse determinado que os efeitos do decisum se aplicariam, em respeito ao disposto nos arts. $1.784 \mathrm{e}$ 1.787 do diploma civil, às sucessões abertas a partir da vigência do Código Civil de 2002, ou a partir da publicação da decisão.

\section{CONSIDERAÇÓES FINAIS}

A Constituição Federal de 1988 reconheceu a união estável entre o homem e a mulher como entidade familiar, podendo esta, se desejassem os companheiros, ser convertida em casamento.

Cumprindo os preceitos constitucionais, em 29 de dezembro de 1994, foi editada a Lei 8.971, que regulou os direitos dos companheiros a alimentos e à sucessão, nesta última parte, assegurou ao companheiro sobrevivente o usufruto de parte dos bens em concorrência com descendente e ascendentes, e ainda o direito à totalidade da herança na falta destes.

Em processo de acompanhamento aos direitos sucessórios do companheiro protegidos pela Magna Carta, em 10 de maio de 1996 foi editada a Lei 9.278, reconhecendo a união estável entre o homem e a mulher como entidade familiar, assegurando aos companheiros o direito de herança e o direito real de habitação.

Com o Código Civil de 2002, o regime sucessório entre companheiros foi aniquilado por meio das regras dispostas no art. 1.790, estabelecendo nítida distinção em direitos sucessórios entre companheiros e cônjuges, demonstrando claro preconceito às relações de convivência não formalizadas pelo casamento.

Em decorrência de inconformismo da lei infraconstitucional, o recurso de um caso concreto chegou ao Supremo Tribunal Federal em sede de repercussão geral, no julgamento do Recurso Extraordinário n 878.694/MG, ocasião em que o referido Tribunal reconheceu e declarou a inconstitucionalidade do art. 1.790 do CC/2002, que regia o efeito sucessório entre companheiros, determinando a imediata aplicação, quanto àqueles efeitos, as regras do art. 1.829 do CC/2002, que trata do regime sucessório entre cônjuges. Com essa decisão, o STF equiparou cônjuges e companheiros para fins sucessórios, tendo o art.1.790 do CC/2002 perdido sua aplicabilidade e julgado inconstitucional.

A decisão supracitada, ao igualar os regimes sucessórios de cônjuges e companheiros, prescrevendo para ambos as regras do art. 1.829 do CC/2002, provocou vários questiona- 
mentos sobre seu alcance, especialmente, em relação a direitos sucessórios do cônjuge que não estavam dispostos no referido artigo, como o direito real de habitação, a inclusão do (a) companheiro(a) como herdeiro necessário e âmbito de aplicação da decisão. Embora tenha o STF sido questionado acerca de tais direitos a serem alcançados, também, pelo companheiro, por meio de embargos de declaração, estes foram rejeitados.

Assim, o STF nada esclareceu na decisão do Recuso Extraordinário n. 878.694/MG quanto ao direito real de habitação do companheiro, uma vez que regra prevista no art.1.831 do CC/2002, figura o cônjuge.

De igual modo, o STF foi omisso quando a inclusão ou não do companheiro no rol dos herdeiros necessários, conforme previsto no art. 1.845 do CC/2002, em que, o cônjuge foi elevado a este patamar.

As duas omissões acima se refletem em outros dispositivos do diploma civil, relativos ao direito sucessório do(a) companheiro(a), como proteção da legítima, colação de bens, direito de moradia, enfim, pairando dúvidas quanto as regras aplicáveis, o que poderia ter sido, rápida e facilmente, respondido pelo STF quando os embargos declaratórios foram interpostos.

Da mesma forma, ficaram em aberto dúvidas e questionamentos sobre a segurança jurídica da referida decisão, posto que, ao ser determinada sua aplicação às sucessões dos companheiros em inventários cuja decisão não teve o trânsito em julgado e inventários extrajudiciais ainda sem escritura de partilha na data da publicação do acórdão, o STF acaba por descumprir as regras dos arts. 1.784 e 1.787 do CC/2002, que asseguram que a sucessão e a legítima são reguladas pela lei vigente ao tempo de sua abertura, bastaria que ele, na própria decisão, tivesse resguardado as disposições dos referidos artigos.

É possível que as decisões judiciais se inclinem equiparando todos os direitos sucessórios garantidos ao cônjuge, também, ao companheiro, entretanto, passados três anos da decisão do STF considerando inconstitucional a ordem de vocação hereditária concedia aos companheiros pelo Código Civil de 2020, a discussão ainda gera discordâncias e polêmicas.

Por fim, lastima-se o fato do STF não ter enfrentado todas estas questões como poderia e deveria, agora o que se espera é que haja o mais brevemente possível uma solução razoável, por parte do legislador, para corrigir evidentes omissões deixadas pelo STF no julgamento do Recurso Extraordinário n $878.694 / \mathrm{MG}$, pacificando a absoluta igualdade entre cônjuges e companheiros, para fins sucessórios.

\section{REFERÊNCIAS}

ANDRADE, Raissa Nacer Oliveira de. Efeitos sucessórios decorrentes da união Estável, após o julgamento do Recurso Extraordinário nº 878.694 no STF. Revista Jus Navigandi, ISSN 1518-4862, Teresina, ano 23, n.5469, 22 jun.2018. Disponível em: https://jus.com.br/artigos/66386. Acesso em: 14 de jan 2020.

BRASIL. Constituição Federal, de 5 de outubro de 1988. Disponível em: http://www.planalto.gov.br/ccivil_03/ constituicao/constituicaocompilado.htm. Acesso em: 03 dez. 2019. 
BRASIL. Lei n. ${ }^{\circ}$ 8.971, de 29 de dezembro de 1994. Regula o direito dos companheiros a alimentos e à sucessão. Disponível em: http://www.planalto.gov.br/ccivil_03/LEIS/L8971.htm. Acesso em: 24 de abr. 2020.

BRASIL. Lei n. ${ }^{\circ}$ 9.278, 10 de maio de 1996. Disponível em: http://www.planalto.gov.br/ccivil_03/LEIS/L9278.htm. Regula o $\S 3^{\circ}$ do art. 226 da Constituição Federal. Acesso em: 27 de abr. 2020.

BRASIL.Lei n. ${ }^{\circ}$ 10.406, de 10 de janeiro de 2020. Institui o Código Civil. Disponível: http://www.planalto.gov.br/ ccivil_03/leis/2002/I10406.htm. Acesso em: 27 de abr. 2020.

FARIAS, Cristiano Chaves de; ROSENVALD, Nelson. Curso de direito civil: parte geral e LINDB: familias, 7 ed. São Paulo: Atlas, 2015.

GONÇALVES, Carlos Roberto. Direito civil brasileiro: direito de família. 6 ed.- São Paulo: Editora Saraiva, 2012.

GONÇALVES, Carlos Roberto. Direito civil brasileiro: direito das sucessões. 9 ed.- São Paulo: Editora Saraiva, 2012.

MEDINA, Paulo Roberto de Gouvêa. Teoria geral do processo. 4 ed. Salvador: JusPodivm, 2019.

PENA JR, Moacir César. Curso avançado de direito das famílias: doutrina e jurisprudência.Teresina: Edufpi, 2017.

PEREIRA, Rodrigo da Cunha. Concubinato e união estável. 9. ed. São Paulo: Saraiva, 2016.

SUPREMO TRIBUNAL FEDERAL. Recurso Extraordinário n. ${ }^{\circ}$. 878.694/MG, Plenário, Relator Min. Luis Roberto Barroso, DJ Nr. 21 do dia 06/02/2018. Disponível em: file://C:/Users/DELL/Downloads/texto_313622639.pdf. Acesso em: 20 de jun. 2020.

SUPREMO TRIBUNAL FEDERAL. Embargos de Declaração no RE 878.694/MG, Relator Min. Luis Roberto Barroso. Disponível em: file:///C:/Users/DELL/Downloads/texto_15338898126.pdf. Acesso em 02 de jul de 2020.

TARTUCE, Flávio. Direito Civil: direito das sucessões.12.ed. Rio de Janeiro: Forense, 2019.v.6.

Recebido/Received: 30.04.2020.

Aprovado/Approved: 04.07.2020. 